\title{
Reseñas
}

\section{El otro Narciso o la imagen degradada de sí mismo ANALÍA ARANCHO'}

\author{
Reseña de:
}

Florencia Abadi. El sacrificio de Narciso. Buenos Aires: Hecho Atómico, 2018.

Poner en juego los vínculos y la subjetividad en tiempos de enorme exposición visual, cuerpos que parecen no tener dueños allí donde gana la despersonalización, reproducción de estereotipos allí donde la soberanía de la subjetividad es aceptada solo si es funcional, si sostiene la estructura... donde no se soporta la pluralidad sino para el espectáculo, donde todo parece ser imagen y virtualidad sin objetos... Parece que el resultado es obvio: podríamos afirmar que este mundo se ha vuelto narcisista.

Pero quizás deberíamos preguntarnos mejor qué entendemos por narcisista. ¿Acaso es el egoísta, incapaz de sacrificar algo, aquél que solo puede amarse a sí mismo, a su imagen? ¿O aquel que fantasea grandeza, absorto en sí mismo y carente de empatía? ¿ $O$ incluso el que envidia a los demás o siente que lo envidian? Podríamos pensar que el deseo subjetivo está más vivo con la democratización de lo que se publica o bien que está aniquilado por el sujeto mismo al desear lo que el otro anhela, en una suerte de estandarización o industrialización del deseo. O muy por el contrario, el mérito sería conseguir que el otro desee lo que le muestro, que me envidie para sentirme deseado.

Una de las tesis principales de El Sacrificio de Narciso, el último libro de Florencia Abadi, filósofa, poeta e investigadora del CONICET (Argentina), es la de proponer una llamativa oposición entre narcisismo y egoísmo. Este trabajo, que la autora llama modestamente "librito", viene a romper con aquella interpretación condenatoria, vinculada a la vanidad, y nos mueve a entender la figura de Narciso como un mito fundante de nuestro arquetipo psíquico, de nuestra cultura. Se trata aquí de entender que el narcisista no es un egoísta, ni alguien que se prioriza a sí mismo buscando frustrar al otro o rechazándolo, pues Narciso en realidad sería más bien aquel que se posterga, para cumplir con el ideal, para ser amado por el otro. 


\section{ANALÍA ARANCHO \\ El otro Narciso o la imagen degradada de sí mismo \\ Reseñas}

La autora nos presenta el sacrificio de Narciso como una propuesta ética y estética. Siguiendo la interpretación de André Gide, Narciso es leído a la luz del ascetismo y la distancia contemplativa, lejos del amor propio y del autoerotismo, como aquella figura subjetiva que sacrifica el yo en favor de la manifestación del ideal. Si la acción puede provocar la pérdida del amado, mejor será contemplarlo, sostener su imagen completa. Narciso se mantiene así servicial para ser reconocido en la devolución de una imagen que cree que es de otro, cuando es su propia proyección. Por eso, debe cumplir con lo que él mismo cree que se le demanda, para no desilusionar, ni desencantar a esa supuesta otredad.

En este marco, la lectura prácticamente canónica de Narciso, a saber la freudiana, es interpelada por Abadi en razón de que "Freud no advirtió la dimensión sacrificial de la estructura narcisista" (p. 82), aquella en la cual el otro es el portador de la imagen ideal que Narciso -forzosamente- busca proteger y por la cual habrá de sacrificarse. No hay desesperación por la imposibilidad de satisfacer el deseo que se genera al enamorarse de sí mismo. Narciso, en realidad, agoniza por el sacrificio que le demanda mantener una imagen; con cada entrada al quirófano, con dietas extremas, con pastillas para mejorar su productividad, sacrifica su cuerpo e incluso su deseo, todo en pos de la imagen que quiere afirmar para el otro. Pero al mismo tiempo, esta lógica narcisista de la represión del deseo propio resulta imprescindible para pensar la constitución de su subjetividad, pues es esto lo que lo lleva a desintegrarse, a perderse en el deseo del otro, pero a la vez lo auxilia, evitando que se vulnere en la carencia de deseo propio, y lo desvincula de la lucha contra la locura, contra la paranoia que lo acecha en la separación y que vuelve hostil las intenciones. Aunque esa completitud a la que se aferra Narciso, procurando resguardarse del mundo, también es un ideal.

Por otra parte, este libro nos invita a devolver la tensión original entre Narciso y Cupido (Eros) que se pierde en la lectura ovidiana. Si Narciso alude a la unidad del yo, Eros es la flecha que lo desquicia. Eros es un dios burlón que goza arrojando flechas, produciendo vínculos a su antojo; con un gesto nos impone el deseo desde afuera, nos muestra lo deseable y nos quita la conciencia. $Y$ en ese deseo impuesto, odiamos, porque la de Cupido es una flecha que el sujeto no se puede quitar, provoca una herida narcisista que lo desafía a restablecerse en su imagen, y en la búsqueda de aprobación queda a merced del otro (p. 35). En El Asno de oro, la célebre obra de Apuleyo, Eros se mantiene oculto de su esposa Psyché. Sin revelar su identidad, goza de ser idealizado por ella, se reconoce suficientemente vasto como para siquiera pensar en que ella puede tener otras necesidades, a diferencia de Narciso, que tiene una imagen degradada de 


\section{ANALÍA ARANCHO \\ El otro Narciso o la imagen degradada de sí mismo \\ Reseñas}

sí mismo, que lo lleva a suicidarse a diario, en el afán cotidiano de ocultar su autodesprecio ( $p$. 80). En este sentido, el narcisista no se mimetiza con el deseo del otro, por el contrario, ignora por completo su propio deseo. Por eso mismo, para la autora, el egoísmo constituye la cura del narcisismo.

El deseo sexual viene ligado al impulso de matar, de apropiarse del otro, de poner límites al deseo del otro. Según Abadi, el odio que acompaña al deseo está ligado a la idealización envidiosa, por lo que no envidiamos un objeto, sino la idealización que hacemos de él. Se trata de un deseo impotente que magnifica la felicidad del otro y desea únicamente cuando el otro posee. Por lo mismo, quiere destruirlo, pues para el envidioso, el rival no se merece lo que tiene. En esta línea la autora realiza un análisis que nos permite reflexionar sobre la misoginia, en cuanto esta sería el resultado de la idealización de un placer que se cree inalcanzable. La mujer es vista -con la mirada bizca de la Envidia- como dueña de un goce inaccesible, que la acerca a lo divino, a lo sublime, que la enigmatiza. $Y$ en esa proyección del deseante que quiere conocer, la vuelve presa de caza. Es una proyección de odio que, velado en la curiosidad y la pasión erótica, esconde su intención destructiva e instala a la mujer en un lugar de misterio hermético que sería mejor no intentar entender, porque "a las mujeres hay que amarlas no comprenderlas", como dice la conocida frase de cuño patriarcal en tono de supuesta admiración. Pero donde hay enigma no habría otro. $Y$ es aquí justamente donde la lectura del sacrificio de Narciso nos permite comprender que Eros no es amor, sino deseo de poseer.

Si la pasión y el deseo son opuestos al amor, no hay entonces amor erótico. Difícil movimiento el que se nos plantea si pretendemos conjugarlos. La lógica narcisista no es tampoco la del amor. En el amor ambos protagonistas, el amante y el amado, son objetos idealizados el uno por el otro, son cómplices, pues "la confianza amorosa detiene el impulso curioso y posesivo del deseo y deja ser a la alteridad" (p. 39). El amor depone las armas y nos permite mostrarnos durmiendo delante del amado, vulnerables, totalmente desprotegidos, babeantes y roncando, cortando con la proyección primitiva "odiante-deseante". Para Abadi, el amor, situándose al margen del goce, de la rivalidad y de la envidia, lejos de los aguijones de la crueldad o del entramado de estrategias, se vuelve más bien piedad, que nos remite a una poco atractiva paz. Sin embargo, no habría supervivencia sin la calidez amorosa, sin el fuego del hogar, sin la dimensión receptiva de la fertilidad, pues "perder el protagonismo es el único modo de alojar a otro y crear un lazo" (p. 29). Pero la previsibilidad de poder contar permanentemente con otro mata la adrenalina instantánea $y$, de la suerte, al erotismo. Al respecto, la autora arriesga dos posibles estrategias para mantener el deseo de lo que ya se 


\section{ANALÍA ARANCHO \\ El otro Narciso o la imagen degradada de sí mismo}

Reseñas

tiene. La primera es la momentánea sustracción del amor, peligrosa revelación que nos deja al borde de la histeria; y la segunda se encuentra en el temor de lo inminente, en la posibilidad de perder al otro, que nos debe mover a su cuidado, pero sin paranoia.

Por fuera entonces de cualquier egoísmo o de un amor propio sobredeterminado, pero también por fuera del circuito piadoso y necesario del amor, se encuentra la lógica narcisista. La ambivalencia freudiana amor-odio en realidad se jugaría en el deseo y el odio, velando la proyección que ambos sujetos hacen del otro como objeto. El narcisismo, en cambio, idealiza sin objeto, rinde culto a la imagen y se sacrifica por ella, creyendo que en esa devoción podrá ocultar su autodesprecio y evitar así el rechazo. La pérdida de la posibilidad de expresar su sacrificio corroe, por omisión, la identidad que procura sostener el narcisista. Si no toma esa oportunidad siente que se delata su vergonzosa verdad, lo faltoso de su existencia, que al mismo tiempo elimina lo que supone es su única oportunidad de ser amado, entregarlo todo.

$Y$ en este giro radical de lo que suele creerse sobre el narcisismo, en este desplazamiento que se produce hacia la dimensión sacrificial donde se pierde el sentimiento de sí, pero también la percepción del otro como tal, ¿qué podríamos decir sobre nuestra pregunta inicial? ¿Vivimos en un mundo narcisista? 